821.163.41.08-1 Дучић J.

https://doi.org/10.18485/sj.2018.23.1.45

МИРЈАНА М. СТАКИЋ САВКОВИЋ

Филолошка гимназија

Београд
Оригинални научни рад

Примљен: 04. 01. 2018.

Прихваћен: 29. 01. 2018.

\title{
ПОЕТСКИ ЈЕЗИК У ПРОГРАМСКОЈ ПЕСМИ ПОЕЗИЈА ЈОВАНА ДУЧИЋА
}

Дучићева програмска песма Поезија у овом раду анализирана је кроз паралелизме са аутопоетичким дискурсом и критичком поетиком њеног творца. С обзиром на чињеницу да у Поезији Јован Дучић 1904. године оглашава своја поетичка уверења о којима такође, у размаку од пола века, пише у различитим критичким и есејистичким записима (али и у другим песмама), настојали смо да покажемо везе између одабране песме и критичких текстова у којима се појављују аналогне објаве. Више од познатих парнасо-симболистичких утицаја на Дучићево стваралаштво, нас је овом приликом занимао однос Дучићевог поетског промишљања народног и поетског језика, тј. функционална примена његових таквих прозних теоријских експликација у конкретној лирској песми.

Кључне речи: поетски језик, стил, програмска песма, аутопоетика, песник, поезија, стварање.

\section{1. УВОДНЕ НАПОМЕНЕ}

Поетски језик Јована Дучића представаљао је инспиративну тему разнородним критичарским увидима и критичком промишљању његовог дела: од Матошевог оспоравања ${ }^{1}$ до суптилних нијансирања и истицања Дучићевих

mstakic24@eunet.rs

${ }^{1}$ Антун Густав Матош истрајно потцртава мањкавости Дучићеве поезије: књижевни снобизам, кварење језика „француштином”, „афектирање”, „ачење”, „анемичан стил”, „безбојне ријечи" (Матош 1952: 225-250). 
драгоцених прилога развитку српског књижевног језика у текстовима Новице Петковића или Ивана Негришорца. Ако би се пажљивије излистао низ аутора који су се овом темом бавили, и сведени пресек њихових запажања потврдио би претежно благонаклоне и афирмативне закључке. Чак и када се имају у виду одређене замерке које су Дучићу упућиване, већина критичара сагласна је при истицању његових заслуга у модернизовању наше поезије, нашег књижевног језика и поетског говора.

„Француза се Дучић понајвише држао у изграђивању свог духовног профила, па тек онда у продубљивању свог песничког света. [...] Такве отмености дикције пре Дучића, а ни после њега, у нашем стиху није било. А ни тако пробране лексике, доведене до једног тако рећи неутралног стања. Вредело је, бар једном у повести нашег песништва, то видети и доживети" (Данојлић 1979: 11-12, 16).

„Дучићев стих је експресиван, звонак, заокругљен, логичан, сликовит, више или мање повишеног тона. Он никад није пресићен смислом, али је ретко празан. [...] Лексички ефектан, он никад није бизаран: његов језички фонд има ретку хомогеност, уза сву несумњиву снажну обојеност. Ако ничим другим, тајновитим преливима и омиљеним обртима, својом оствареношћу тај стих је индивидуалан, и у нашој поезији јединствен" (Павловић 1981: 305).

„Занатска вештина, разуме се, мења место и значај у еволуцији сваке уметности, па и песничке. Али код Дучића - што мало ко запажа - исте особине има и реченица у путописној и медитеранској прози: звучна, мелодична, дисциплиновано вођена и пажљиво склопљена. За њу већ можемо рећи да је представљала језичку тековину која је шира од песничке, јер је суделовала у стабилизовању разрађених синтаксичких структура, као нешто касније и другачије Андрићева реченица" (Петковић 2001: 3-4).

„Мајстор форме Јован Дучић је поставио бриљантне стилске стандарде. [...]Углађеност исказа и пробране лексике, песник систематски елиминише стилске „огреботине” попут брутизама, дијалектизама, провинцијализама, архаизама, а поготово турцизама и свих трагова Истока у српском језику и култури. [...] Дучић је конституисао класичан стил српске модерне књижевности" (Негришорац 2009: 19).

Одабрани цитати подсетили су на познату чињеницу да је Јован Дучић истраживан и промишљан песник, те да је његов поетски језик и песнички израз подстицао врло инспиративне критичке изражаје о стваралаштву некадашњег кнеза песника. Међутим, нама се посебно интересантним чини истраживање које би нас повело ка Дучићевом промишљању издвојене теме, ка његовом проговору о поетском језику и стилу, односно корелативу између таквих Дучићевих стваралачких експликација у аутопоетичким записима и њихове поетске обраде. Наиме, из Дучићевих прозних списа и програмских песама могао би се издвојити један изнијансиран аутопоетички регистар (његових ставова о стилу, језику, поетском говору), који би послужио као ин- 
спиративан (каткад и сасвим поуздан) путоказ тумачењу ${ }^{2}$. На основу Регистра који смо за потребе овога рада оформили, приступићемо тумачењу Дучићеве песме Поезија са циљем да укажемо и на такву могућност аналитичког приступа (заснивање тумачења лирске песме у поетичком дискурсу и критичкој поетици њеног творца).

\section{2. КЊИЖЕВНОТЕОРИЈСКИ ПРЕДЛОЖАК СТИЛИСКО-ЈЕЗИЧКОЈ АНАЛИЗИ}

У поетском и књижевно-критичком раду Јована Дучића као честе и препознатљиве теме појављују се песма, песник, и стваралаштво - духовно полазиште душевно уточиште и специфичан одраз народног (општег) језика у индивидуалном поетском изразу ствараоия. Ово се нарочито односи на Дучићеве критичке текстове и есеје. Неколико је израженијих линија којима Дучић-есејиста развија своју критичку мисао о стваралачким изазовима и искушењима:

• проучавање књижевно-историјских појава и разнородних културолошко-поетолошких искустава других народа (пре свих, Француза) зарад компарирања са традицијом и актуелним тенденцијама домаће књижевне сцене;

„Да поезија парнасоваца није префинила нерве и образовала опажања, истанчала наша чула, ко зна да ли би било у нама могућности за ону танану поезију символа, за ону,такорећи, метафизику осјећања која данас улази срећом у стиховану књижевност. [...] Зато је поезија Форме морала да претходи поезији Идеје, која са Метерлинком и друговима у Француској, а Демелом, Хофмансталом, и Георгом у Њемачкој постаје једина поезија свога времена" (Дучић 2001: 208-209; из текста Споменик Војиславу).

• критичко полемисање са делима књижевних предака (и савременика) поводом истраживања, (пре)испитивања, изоштравања и излагања сопствених аутопоетичких ставова;

„Затим, реализам снима али не ствара; и зато, чим један опис оде од стварног у хипотетично, онда је то крај реализма. Реализам је сликање свачијег, полутанског и вулгарног. Реалист нема мишљења ни о чему; а реализам, то је само говор о инстинктима" (Дучић 2001: 124; из есеја Иво Ћипико).

- начелна размишљања о песнику, песми и стварању у којима аутор (есејиста/критичар) излаже оформљене ставове и закључке, очигледно проистекле из личног стваралачког искуства, итд.

${ }^{2}$ Дучићева мисао о језику и поетском говору јесте целовита и прилично конзистентна. Међутим, да би се сагледала у целини, за њом је потребно трагати по различитим ауторовим есејима и критикама. Стога се чини важним један овакав покушај груписања и синтетисања његових разасутих ставова како би се показало да су питања језика, песничког израза и стила у Дучићевим критичким и есејистичким текстовима детаљно разматрана, континуирано обрађивана и доследно испитивана. 
„Уверен сам, уосталом, да је и код највећих песника њихова најлепша песма остала ненаписана; јер је тешко доћи до речи и до изражаја баш у најдубљим стварима људског духа.[...] Отуда мучење највећих и најискренијих писаца, њихова стална тражења да једну исту мисао сваки пут кажу друкче" (Дучић 2001: 70; из есеја Милорад J. Митровић).

• промишљање народног епоса и језика народне књижевности (пре свега, „гусларског десетерца”) као подстицајних полазишта за књижевноуметничко стварање и формулисање индивидуалног/оригиналног поетског говора;

„Наши добри слепци гуслари оставили су нам најколорисаније и најсјајније примесе символа; наши слепци су нас учили како се од једног сељачког језика прави високи песнички говор. А имамо славних песника без иједне славне фигуре. Није песников посао да изграђује народни језик; то је дело народа. Али он тај језик прави способнијим за изражавање већих замисли, и то спиритуализујући тај језик” (Дучић 2001: 196; из есеја Исидора Секулић).

Када се брижљиво проучи књижевно-критички и есејистички рад Јована Дучића, постаје јасно да ови текстови ${ }^{3}$, представљају поуздан кључ за одгонетање Дучићевих песничких светова. У критичкој мисли о стваралаштву других садржана је иманентна поетика самог аутора, те је тешко замислити било какво озбиљније истраживање Дучићевог песништва које би се оглушило о исказе/идеје записане у Градовима и химерама, Благу изара Радована, Јутрима са Леутара, Мојим сапутнищима. И обратно. У тематско-мотивским, версификацијским и стилско-језичким слојевима Дучићевог песничког дела неретко одзвањају књижевно-критичке рефлескије из његових есеја.

Давне 1888. године написао је Мелем болу, песму у којој, слично Шантићу (у Музи), и Дучић заговара лековиту моћ поезије ${ }^{4}$. Након педесет година, у Песми (1938), аутор заокружује своје лирско тематизовање песничког стваралаштва, потцртавајући божанско порекло песме, њену свеприсутност и свемоћ: „Господ ме сеја целом шаком / У часу светлу и голему, / Да будем јутро дану сваком, / И његов глас и кључ у свему" (Дучић 1989: 305). А у међувремену, настајале су: Хајд 'мо, о Музо! Амо милу руку (1900), Зашто? (поетска проза из 1901), Сунце (поетска проза из 1903), Поезија (1904), Дело (поетска проза из 1905), Пут (1906), Песма (1909), Стварање (1914).

Одабране песме карактеристичне су по томе што се у целости баве поетичким темама и њиховим лирским обликотворењем. Извесно је, такође,

\footnotetext{
${ }^{3}$ Јован Дучић се књижевном критиком и есејистиком бавио од 1893. до 1943. године, дакле до краја свог живота. Он књижевност и језик није тумачио само у критикама које су разматрале рад одређених писаца или њиховог стваралаштва, већ су сви његови критички записи (и они о ликовним уметностима, о савременим културолошким концептима, о преводилаштву, научној прози, књижевној периодици, итд), представљали значајан извор за разумевање ауторовог критичког мишљења о одређеним књижевно-језичким темама, појавама, питањима.

${ }^{4}$ Песму Мелем болу Јован Дучић је објавио у сомборском часопису Голуб, 1888, X, 7, 101. Ова песма је остала изван Дучићевих Сабраних дела (1929), а сведочи о романтичарским утицајима Змаја и Радичевића на његово рано стваралаштво.
} 
да и у другим Дучићевим песмама постоји парцијална обрада ових мотива 5 . Наиме, естетска и поетска стварност, песма, песник и стварање у Дучићевом песништву појављују се и као тематски оквири, и као субмотиви, и као објективни светови са којима се самерава целокупни реалитет постојања. Пошто присуство поменутих мотива представља топос Дучићевог свеукупног стваралаштва (поетског и прозног), варијације таквих мотива унутар комплекса програмских песама очекивано су и најочигледније. Своје песничко вјерују аутор сугерише различитим моделима објаве: алузивно, метафорички, алегоријски, симболички, сугестивно - истрајно пребирајући по језику у потрази за оним оригиналним личним изразом којим би се достојно исказао.

Један од таквих песничких покушаја јесте Поезија, програмска песма којом се Дучићева аутопоетика и данас представља у школским читанкама, а коју је својевремено, међу другим Дучићевим песмама ове врсте, Богдан Поповић сматрао понајбољом и достојном Антологије новије српске лирике. Дакле, више од једног века Дучићева Поезија се чита, разумева и предочава као својеврстан (ауто)поетички проглас нашег песника. Иако се донекле можемо сложити са оним мишљењима која указују да ово није најбоља Дучићева поетичка песма ${ }^{7}$, сматрамо да јесте кључна и да је разумевање Поезије драгоцено за анализу и тумачење осталих (поетичнијих, тешко и поетичкијих) Дучићевих песама. Разлог томе је и чињеница да је Поезија Дучићева најранија и најубедљивија лирска експликација парнасистичких (и само донекле симболистичких) програмских начела, примењиваних у другим, а још 1904. године оглашених у овој песми. Такође, могло би се устврдити да је управо у овом сонету Дучић најраније и најверније применио свој став о неопходности спиритуализације народног (општег) језика при формулисању аутентичног и препознатљивог песничког говора (поетског језика), заснованог у личном таленту једног песника. Уосталом, стихови записани у Поезији стоје у директној вези са поетолошким објавама које се проналазе у Дучићевој есејистичкој прози.

Детаљнији увиди у Дучићеву критичку поетику, успостављану у његовим прозним текстовима, указали су на могућност формирирања једног регистра појмова који би представљао сажетак Дучићевих речи о стилско-језичким

\footnotetext{
${ }^{5}$ На пример, Соната (1905), Стихови (1906), Бескрајна песма (1910), Семе (1938), итд

${ }^{6}$ Од Дучићевих програмских песама, издвојених у овом раду (а објављених до 1911), у Поповићевој Антологији новије српске лирике нашле су се четири: Хајд'мо, о Музо! Амо милу руку (као уводна песма Антологије), Зашто?, Моја поезија (доцније преименована у Поезија), Суние.

${ }^{7}$ Иако у тексту Поезија као унутрашња светлост: поетичке песме Јована Дучића посвећује достојну пажњу интерпретацији Поезије, Иван Негришорац категорично истиче: „Имајући на уму ширину и обухватност поетичког дискурса у поезији Јована Дучића, требало би јасно рећи да кључни његов аутопоетички прилог није песма „Поезија” већ песма „Песма” (1909)" (Негришорац 2009: 30).
} 
стваралачким изазовима. Регистар одабраних појмова који у наставку рада представљамо селектован је из Дучићевих критичких текстова и есеја, а критеријум за формирање оваквог појмовника били су ауторови теоријски ставови о песништву, о књижевном језику, језику књижевности, народном језику, поетском језику и стилско-језичким начелима стварања. Са једне стране, намера нам је била да покажемо Дучића као писца који се истрајно бавио промишљањем језичких питања, а са друге, Регистар смо оформили како бисмо из таквог предлошка размотрили Дучићеву примену сопствене теоријске мисли у конкретном песничком делу 8 .

\begin{tabular}{|c|c|}
\hline \multicolumn{2}{|r|}{ ЈОВАН ДУЧИЋ: РЕЧИ О ЈЕЗИКУ } \\
\hline РЕГИСТАР & ОДАБРАНИХ ПОЈМОВА ИЗ ЕСЕЈА И КРИТИКА \\
\hline $\begin{array}{l}\text { (Вече код песника } \\
\text { Јована Дучића) }\end{array}$ & $\begin{array}{l}\text { „Пишите везане стихове, јер слободан стих се теже памти и у } \\
\text { њему се теже примећује индивидуалност. У слободном версу } \\
\text { сви песници постају слични. Рима је императив природе и } \\
\text { живота. Две капи са стене падну и, ето рима. Два суха листа } \\
\text { падну са гране, па опет, ето рима! Ритам је дошао од срца. } \\
\text { Зар само куцање срца не подсећа на ритам! Везан стих је } \\
\text { постанак поезије, он ће дати и њен крај - ако је он уопште } \\
\text { могућ. Ако је музика могућа без акорда, онда је поезија } \\
\left.\text { могућа без рима” (Дучић } 1969^{a}: 272\right) \text {. }\end{array}$ \\
\hline $\begin{array}{l}\text { (У есеју Иво } \\
\text { Војновић) }\end{array}$ & $\begin{array}{l}\text { „Велика поезија, то су само извесна места из Дантеа, и } \\
\text { неке строфе из Петрарке, и неки делови Шекспира, и неки } \\
\text { стихови из наших народних песама. Значи, велика поезија, } \\
\text { то су песме са највећим мотивима људске судбине и писане } \\
\text { највишим људским изражавањем (Дучић } 2001: 11 \text { ). }\end{array}$ \\
\hline $\begin{array}{l}\text { (У есеју Милорад } \\
\text { J. Митровић) }\end{array}$ & $\begin{array}{l}\text { „Лирски песник је филозоф који иде до крајње границе } \\
\text { трансцендентног и општег. Зато кад филозофија достигне } \\
\text { до свог врхунца, она постаје поезијом-лириком. Песник није } \\
\text { ни шумски човек ни кафански разбибрига, него кабинетски } \\
\text { радник и учени занатлија на тешком послу риме и ритма” } \\
\text { (Дучић 2001: 54). }\end{array}$ \\
\hline
\end{tabular}

${ }^{8} \mathrm{C}$ тим у вези напомињемо да је у заграду иза сваке одреднице Регистра уписан број који ће у каснијој анализи означавати везу између садржаја те одреднице (или ставова из ње преузетих) и одговарајућег сегмента песме Поезија. 


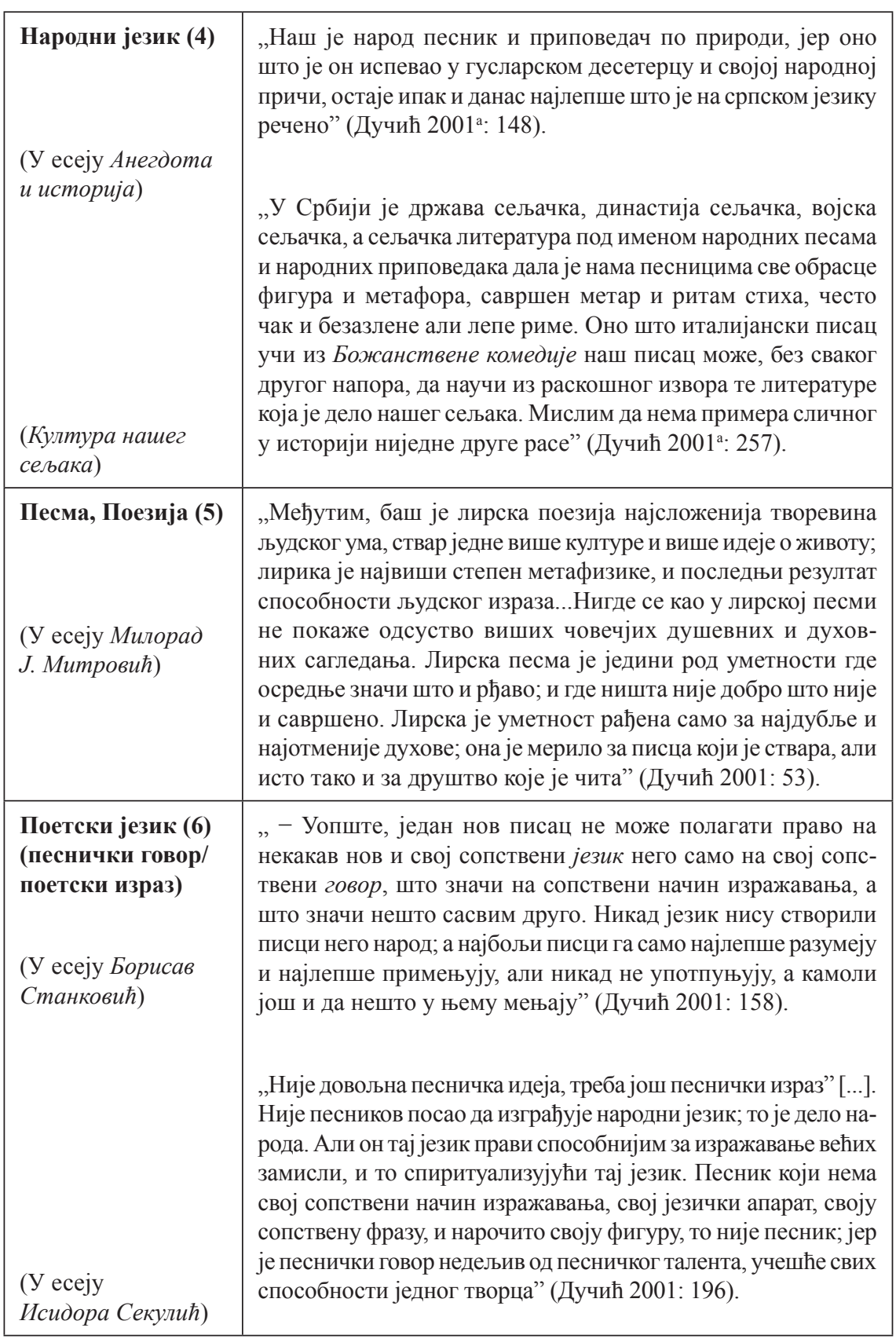




\begin{tabular}{|c|c|}
\hline $\begin{array}{l}\text { Реч (7) } \\
\text { (У есеју } \\
\text { Исидора Секулић) }\end{array}$ & $\begin{array}{l}\text { „Реч није готово дело, него материја која мења своје облике } \\
\text { према томе у чијим се рукама налази; у рукама доброг ар- } \\
\text { тисте она је ствар алхемије” (Дучић 2001: 196). }\end{array}$ \\
\hline $\begin{array}{l}\text { (У есеју Милорад } \\
\text { J. Митровић) }\end{array}$ & $\begin{array}{l}\text { „Реч је живо створење, које има своју персоналност и свој } \\
\text { обим, своју пластику и своју тежину. Реч често само нешто } \\
\text { каже, констатује и прецизира, али ништа даље не евоцира. } \\
\text { Реч има свој врло узак свод резонанце; и зато се велики из- } \\
\text { ражаји казују оним што једно дело сугерише, а не оним што } \\
\text { оно каже. Међутим, ниједан песник не зна колико је својим } \\
\text { делом сугерисао и евоцирао, макар и знао све шта је рекао. } \\
\text { Зато је трагање свих песника за ненаписаном песмом нешто } \\
\text { трансцендентно, што и њега самог надвисује и натпева поет- } \\
\text { ских наговештаја, омиљених у символизму, врхунац лирске } \\
\text { лепоте” (Дучић 2001: 72). }\end{array}$ \\
\hline $\begin{array}{l}\text { (У есеју Борисав } \\
\text { Станковић) }\end{array}$ & $\begin{array}{l}\text { „Највећи је писац, напротив, онај који пише нејлепшим } \\
\text { језиком, али нарочито онај који пише најбољом синтаксом! } \\
\text { Само потпуно расни људи пишу добром синтаксом свог } \\
\text { народног језика. Наши писци који нису расни, а њих има } \\
\text { много, и свакако више него што би нам требало, пишу } \\
\text { српским језиком који је за нас остале неразумљив, или бар } \\
\text { непријатан, најпре по тој синтакси. Они су неразумљиви и } \\
\text { непријатни јер не говоре српском синтаксом, и кад пишу } \\
\text { српским речима. Синтакса, то је геометрија мисли; она је } \\
\text { строго везана за крвоток и пулс, за дах и предах човека, из } \\
\text { чије је крви тај језик поникао” (Дучић 2001: } 158 \text { ). }\end{array}$ \\
\hline $\begin{array}{l}\text { (У есеју Милорад } \\
\text { J. Митровић) }\end{array}$ & $\begin{array}{l}\text { „Борба између духа и форме, значи борба између мисли и } \\
\text { речи, то је очајна борба уметникова до краја његовог живота. } \\
\text { Свака песма је поникла из једне гомиле емоција, слика, речи } \\
\text { и сликова, међу собом помешаних, и често противуречних. } \\
\text { А запитајте ма којег истинског песника да ли је уопште и } \\
\text { приближно успео да напише оно што је највећма желео. } \\
\text { Многи су чак написали сасвим друго и сасвим друкче него } \\
\text { што су желели. Реч заводи мисао као матица што заводи } \\
\text { предмет на брзој реци. Ритам наметне сасвим друкчи ток } \\
\text { нашој мисли него онај којим је она спочетка била пошла; } \\
\text { и слик извитопери метефору. Најбољи доказ за ову борбу } \\
\text { песника с песмом, то су мученички напори, и то баш највећих } \\
\text { твораца, који трају све док изгладе и коначно усаврше једну } \\
\text { своју песму” (Дучић 2001: 71). }\end{array}$ \\
\hline
\end{tabular}




\begin{tabular}{|c|c|}
\hline $\begin{array}{l}\text { (У есеју } \\
\text { Исидора Секулић) }\end{array}$ & $\begin{array}{l}\text { „Има један језик којим говоре само пророци и песници. } \\
\text { Да се опише једна песничка визија или велика песнича } \\
\text { емоција, треба крупно средство песничког израза. Свеци } \\
\text { и мистици имају свој начин говора који је прост, али који } \\
\text { је сублиман и недостижан у његовој простоти. Могу се и } \\
\text { необичне песничке мисли говорити обичним речима, јер све } \\
\text { су речи обичне, али не смеју се говорити обичним фигурама. } \\
\text { Велики творац се и не служи у крупним моментима само } \\
\text { речима, које су лексикографска средства, него фигурама, } \\
\text { које су средства књижевног израза. Није довољно добро } \\
\text { знати народни језик, треба још имати снаге да се на њему } \\
\text { прави своја лична метафора. Сваки писац већег стила је } \\
\text { пре свега већи од других по том што има свој начин говора: } \\
\text { изражавамо се народним језиком који је општи, али својим } \\
\text { личним говором” (Дучић 2001: 196). }\end{array}$ \\
\hline $\begin{array}{l}\text { (Споменик } \\
\text { Војиславу) }\end{array}$ & $\begin{array}{l}\text { „Материја је свагда материја, нијема, мртва, несамостална, } \\
\text { ограничена. Она недостаје сама себи. Форма у пјесми може } \\
\text { да често замијени све друго, а садржина често може да буде } \\
\text { све друго само не поезија. Све је до тога како се нешто рече. } \\
\text { Ријеч је често оно библијско Слово које наређује да буде } \\
\text { свијет из ништа, и да се роди свјетлост. Прави пјесник-ар- } \\
\text { тиста може да рече: дајте ми парче мокре земље па да вам } \\
\text { даднем Венуса!” (Дучић 2001: 208). }\end{array}$ \\
\hline
\end{tabular}

\section{3. СТИЛСКО-ЈЕЗИЧКА АНАЛИЗА У СВЕТЛУ ПОЕТСКОГ ЈЕЗИКА}

\section{Поезија}

Мирна као мрамор, хладна као сена, Буди одвећ тужна са сопствених јада, Ти си бледо тихо девојче што снева.

Да би ишла икад да тешиш ко страда, Пусти песма других нека буде жена, А чедна, да водиш гомиле што нагле. Која по нечистим улицама пева.

И стој равнодушна, док око твог тела,

Ја не мећем на те ђинђуве са траком, Место китњастог и раскошног одела, Него жуте руже у те косе дуге:

Лебди само прамен тајанствене магле. Буди одвећ лепа да се свиђаш сваком, Одвећ горда да би живела за друге. 
Програмска песма Поезија објављена је 1904. године у Српском књижевном гласнику под насловом Моја поезија. У збирци Песме (1908) Дучић задржава овај првобитни наслов, да би је у коначној верзији својих Сабраних дела (1929) преименовао и насловио општије-Поезија. Овакав поступак јесте практична примена његових уверења о „борби песника с песмом” и о њиховим „мученичким напорима који трају све док не изгладе и коначно усаврше једну своју песму" (Р: 9)9. Ово потврђује и чињеница да је коначна верзија песме претрпела одређене лексичке, стилске, версификацијске па и значењске измене, те да је двадесетак година била предмет Дучићевог „кабинетског и занатлијског рада на тешком послу риме и ритма" (Р: 3$)^{10}$. Са друге стране, преименовање наслова указује и на песникову сугестију да поетичка начела исказана у Поезији нису тек поетско уобличавање једног индивидуалног стваралачког принципа, већ начело једног песничког програма у индивидуалној поетској објави.

Будући да у Поезији Јован Дучић, пре свега, објављује своју визију парнасистичког песничког програма (који је, уз одређена нијансирања, заједнички припадницима и следбеницима овог књижевног покрета), оригиналност Дучићевог индивидуалног приступа познатим програмским начелима не одмерава се његовим поетолошким рефлексијама ни садржинским планом песме, него начином на који аутор о томе говори, дакле формом песничког дела и посебношћу његовог поетског језика. Заснивање оваквог приступа тумачењу своје полазиште, између осталог, проналази и у значају који је сам Дучић приписивао поетском језику (Р: 6). Када се ради о поетском језику у овој програмској песми, уочљива су два паралелна тока: поетски проговор о језику и његова примена у поетском поступку.

У првом катрену овога сонета успоставља се контрастирање поетских инструкција (афирмисање пожељних, доличних стваралачких принципа) са поетским оповргавањима (оспоравање непожељних, неприхватљивих стваралачких поступака). Започети паралелизми развијаће се кроз целу песму, те се и

${ }^{9}$ Како је већ раније назначено, у стилско-језичку анализу песме биће утиснуте и Дучићеве теоријске мисли које представљају аналошке ставове и одговарајуће корелативе са његовим програмским објавама и песничким мислима о поетском језику, инкорпорираним у песму Поезија. Такве везе између истоветних ставова изложених, са једне стране у критичким и есејистичким текстовима, а са друге у програмској песми Поезија означићемо одговарајућим упутницама на Регистар. Свака упутница садржи почетно слово Р (Регистар) и број конкретне одреднице, нпр. P:1 (1. одредница у Регистру), Р:2 (друга одредница у Регистру), итд.

10 Наиме, у СКГ (1904, XII, 8, 1235) под насловом Моја поезија стајали су мало другачији стихови: „Мирна као мрамор, тиха као сена, / Ти си бледо, сетно девојче што снева / Пусти песма других нека буде жена / Што по нечистијем тржиштима пева. //... Буди одвећ горда да живиш за друге... // И на бледом челу са символом јада, / Буди одвећ тужна да тешиш ко страда, / И чедна да волиш гомиле што нагле. // И стој равнодушна, док око твог тела, / Место китњастога раскошног одела, / Лебди само прамен тајанствене магле" (Дучић 1989: 328). 
двострука метафоризација поезије-девојчета / поезије-жене доследно прелива у алегоријски антитетички принцип, присутан у свакој строфи. У почетним стиховима првог катрена поезија се метафорички идентификује са сликом девојчета (мирног, хладног, тихог, сањалачког). Оваква слика представља полазиште и за еквивалентну сугестију (инструкцију) о пожељном стилско-језичком изразу. Аналогно представама које сугерише поезија-девојче, decorum поетског језика подразумевао би: лексичку једноставност, синтаксичку геометрију мисли, стилску уздржаност, скромност, прикладност, непретенциозност (Р: 7, $8,10)$. Супротно таквом начелу уздржаности стоје вулгарна пренаглашеност, предвидивост и стилско-језичка накинђуреност које аутор критички оповргава и изопштава из прихватљивог стваралачког модела: „Пусти песма других нека буде жена, / Која по нечистим улицама пева”. За разлику од девојчета, окренутог себи и свом сневању (ларпурлартистичка имагинација поетске стварности), слика жене из првог катрена поистовећује се са поетском обрадом недоличних тема, са реалистичним снимањем и сликањем свакодневице - оног „свачијег, полутанског и вулгарног” (утилитаристичко прислуживање засновано у поетском преузимању опипљиве реалности, оглушено о изазове творачког устројавања аутохтоне поетске стварности). Жена која по нечистим улицама пева доступна је и разумљива многима: она је упадљива, пренаглашена, наметљива. Она је одраз неприкладног и недоличног поетског израза - прегласног, нападног, очекиваног, упрошћеног, уобрученог кичом. Таква жена је попут обичне речи (материја). Она је огољена констатација и вулгарни прецизни исказ. Није ни оплемењена ни одуховљена, није поетска сугестија. Та реч није преображена узвишеним поетским изражајима свога творца који ју је захватио из познатих језичких залиха само да би је винуо у њено ново, прикладно обличје: оно познато, али не и спознато (Р: $5,7,9)$.

На лексичком плану Дучић у Поезији остаје доследан прокламованом стваралачком маниру који подразумева чистоту, углађеност и пажљиви одабир речи. Све лексеме у песми сврховито се уланчавају око основних: девојче и жена. Указујући на раслојеност и различитост женског света (и женског принципа објаве), идентификујући притом свет жена са светом поетског дела, аутор брижљиво групише одабране лексеме у припадајући корпус пожељног или непожељног стваралачког обрасца. У оба случаја дескриптивни колорит доминантно се заснива на описним придевима. Тако у корпусу речи уз девојче-поезија стоје придеви: мирна, хладна, бледо, жуте, дуге, лепа, горда, тужна, сопствених, чедна, равнодушна, тајанствена, а у корпусу жена-поезија: нечистим, китьастог, раскошног. Слично је и са именицама. Уз девојче-поезију групишу се именице: мрамор, сена, руже, косе, јади, тело, магла, а уз жену-поезију: улице, Ђинђуве, трака, гомиле, одело. Уз девојче-поезију доследно стоје личне и присвојне заменице: ти, те, твог, а уз жену-поезију: односне заменице која, ко и општа заменица сваком. И употреба глагола је 
на истом трагу. Девојче-поезија призива глаголе: сневати, пустити (друге), метати (жуте руже), бити (одвећ лепа/тужна), стајати (равнодушна), лебде$m и$ (прамен магле); а у групи глагола сврстаних уз жену-поезију стоје: певати (по нечистим улицама), метати (ђинђуве са траком), свиђати се (сваком), живети (за друге), тешити (ко страда), водити (гомиле што нагле). Без обзира на врсту речи и на различитост њиховог значења, ипак је могуће препознати обједињујући критеријум за избор лексема и њихову функционалну примену у поетском језику ове песме. Лексички фонд сврставан уз девојче-поезију сугерише пожељни стваралачки и естетички принцип интровертности (доминација именица и придева, тј. идеја о поезији која се њима сугерише), док лексички регистар приписиван жени-поезији означава оповргавани и неприхватљиви принцип стваралачке и естетичке екстравертности (фреквентнија је употреба одабраних глагола, тј. радњи на које се њима упућује) .

Антитетички принцип огледања пожељног са непожељним стилскојезичким изражајима у другој строфи заоштрава се наглашавањем присуства лирског субјекта: песника-творца, песника-мислиоца, инструента-опонента. Његово заступање пожељног и опонирање неприхватљивог песничког изражаја сада је усмерено ка тематизовању доличног стила: „Ја не мећем на те ђинђуве са траком, / Него жуте руже у те косе дуге". Дакле, у првом делу друге строфе поетски субјекат говори о личној, проживљаваној борби између духа и форме (између мисли и речи). Он истиче значај потраге за прикладним фигурама које су, за разлику од речи („,обичних лексикографских средстава”), достојнија средства књижевног израза (Р: 10). Адекватност стила доживљава као потенцијалну формулу за разрешење очекиваних стваралачких немира у несигурним тумарањима и потрагама за достојним језичким изразом ненаписане песме $(\mathrm{P}: 9,10,11)$. Негирањем и оспоравањем језичке бижутерије, песник-творац афирмише природност језичког израза. Све спољашње интервенције и видљиви наноси украса, свака кићеност и бомбастична употреба језика (Ђинђуве са траком) за њега предствљају јалов и недостојан стваралачки манир. Одлике доличног стила емблематски су представљене сликом жутих ружа у дугим косама девојчета. Овакво решење упућује на исконски девојачки ентитет заснован у њеној природној лепоти. Таква треба да буде и песма: кохерентна и обједињена у стилској адекватности, ненаметљивости и доследности. Коса као природни украс девојчета упућује на аутохтони стилски интегритет поетског дела, а наглашавање дужине те косе истовремено означава очекивану целовитост доличног стилског изражавања у примени принципа јединства песничког обликовања. Прикладни стил је означен као интегративни и неопходни чинилац ваљаног поетског језика, а примењивани поетски језик представља потврду песникове способности (или неспособности) да народани језик спиритуализује, да од обичних речи ствара необичну фигуру, да устроји лични језички апарат за препознатљиво изражавање сопствених мисли (Р: 6). Најзад, поетски 
језик би требало да буде ненаметљиво инкорпориран у естетички принцип лепоте по себи и усаглашен са стваралачком визијом ненаметљиве, недокучиве, исконске лепоте песничког дела - лепоте која измиче пред баналном потрагом за очекиваним. Значењска блискост синтаксичких паралелизама између последња два стиха првог и другог катрена препознаје се управо по аргументацији која успоставља поменути естетички принцип иманентне лепоте. Императивно интонирани стихови у првом случају представљају песниково оповргавање: очигледности, приземности, неусклађености, предвидивости, разоткривености, баналности поетског језика и песничког дела („Пусти песма других нека буде жена, / Која по нечистим улицама пева"). У другом катрену императивно интонирани стихови афирмишу аутохтону лепоту поезије која је заснивана у узвишености, суптилности, хармоничности, елеганцији, љупкости поетског израза и песничког дела („Буди одвећ лепа да се свиђаш сваком, / Одвећ горда да би живела за друге). За разлику од жене-позије која је окренута и означена другима (социјално ангажована, односно укаљана атмосфером нечистих улица), девојче-поезија траје у својој недодирљивости, у једноставности која призива нежност и сугерише духовност.

О пресудној улози доличног стила у поетском устројавању једног дела, Дучић је теоријски мислио (Р: 10), а из таквог начела практично делао. Поетичко разматрање прикладног стила у песми Поезија најизраженије је у другом катрену, али је поетска примена изречених ставова видљива у целом сонету: брижљиво бирана и усклађивана лексика; једноставност, јасноћа, разговетност и углачаност израза; доследно, а ненаметљиво украјање, личне метафоре" у контекст казивања. Сагласно са успостављеним стилским критеријумима, Дучић је и у овој песми „несклон свим оним поступцима, попут звучних поигравања, игре речима, параномазије, каламбура и других фигура које расипају смисао по семантичким тривијалностима и акциденталијама" (Негришорац 2009: 19). Напротив, његове фигуре су скровитије и углавном синхронизоване са семантичким и идејним слојевима дела. Рецимо, алегоријска доминанта у Поезији на стилском плану одражава песникове идеје о значају сугестивности, тајанствености и флуидности једне песме. Епитетска доминанта одговара песниковом настојању да опише и изложи обрасце пожељног и непожељног стваралачког манира, а контрасти представљају стилску основу за сучељавање два супротстављена творачка концепта. Дакле, у алегоријски предложак, формиран контрастирањем метафорички уобличених опонената (поезије-девојчета и поезије-жене) уграђују се, и са њим усклађују, преостала стилска средства. Тако се у успостављену алегоријску схему утискују: епитети (мирна, хладна поезија, бледо, тихо девојче, нечистим улицама, жуте руже, дуге косе, лепа, горда поезија, тужна, чедна, равнодушна песма, китњастог, раскошног одела, тајанствене магле), метафоре (девојче, жена, нечисте улице, Ђинђуве са траком, жуте руже, косе дуге, тело, китьасто и раскошно одело, 
лебди прамен тајанствене магле), поређења (мирна као мрамор, хладна као сена), контрасти (Мирна као мрамор, хладна као сена, / Ти си бледо тихо девојче што снева, / ППусти песма других нека буде жена, / Која по нечистим улицама пева; Ја не мећем на те Ђинђуве са траком, : Него жуте руже у те косе дуге;), инверзије (анастрофичне тенденције - косе дуге, свиђаи сваком, ca сопствених јада; хипербатонске тенденције - Да би ишла икад да тешии ко страда), метонимија (гомиле што нагле).

Поезија је испевана у везаном стиху, у симетричном дванаестерцу, са доследном цезуром иза шестог слога (александринац). Осим изосилабичности (једнак број слогова у сваком стиху), ову песму карактерише и трохејски ритмички импулс (тенденција да сваки непарни слог буде наглашен, а парни ненаглашен). Када се ради о ритмичком фразирању, приметно је да акценатске границе изостају иза непарних слогова и имају тенденцију да буду иза парних. Дакле, стихови су углавном трохејски, а акценатске целине парне. Опкорачења се јављају само унутар строфа. Тако је у песми остварен уједначен ритам којим је обликован и њен садржински план: заступање отмености, смирености, уздржаности, хомогености и хармоничности (Р: 3 ). Императивне инструкције записане у првом терцету развијају ово поетско суочавање пожељног принципа стваралачке меланхолије (због свести о узалудним напорима да се досегну највиши језички изражаји; Р: 2) са неприхватљивим стваралачким удовољавањем псеудолонгиновским ситним бригама и ропским мислима којима се никада не достиже дубоко и надахнуто осећање, ни способност за велике замисли, ни племенитост израза, ни стилско узрастање: „Буди одвећ тужна са сопствених јада, / Да би ишла икад да тешиш ко страда, / А чедна, да водиш гомиле што нагле". Без обзира на извесност стваралачких јада, лирски субјекат не прихвата осредњост. Он поезију види као девојче, а поезија-девојче представља инстинктивни призив лепог. Она је узвишена, и искупљујућа. Она је пространство духа и подстицај мученичких песникових напора да изнађе поетски језик достојан њене аутентичне, природне лепоте (Р: 9).

Ако је поетско обликовање у првом терцету назначено сугестијом стваралачке меланхолије, оно у другом терцету постаје стожерни мотив. Структурално вајање, песничко обликотворење и форма једне песме морали би да надилазе очекиване моделе стереотипних наноса и устаљених језичких плаштова: „И стој равнодушна, док око твог тела, / Место китњастог и раскошног одела, / Лебди само прамен тајанствене магле". Дучићева теоријска мисао о значају форме која у једној песми може да замени све друго (Р: 11), у последњим стиховима Поезије добија своју аналошку поетску транспозицију. Наиме, Дучићево стваралачко оглушавање о схему традиционалног компоновања сонета у овој песми није условљено ни непознавањем правила ни ауторовом невичношћу да одговори постављеним захтевима. Напротив, чини се да је овде реч о свесном избору и о модернистичком ремодулирању 
задатих правила, те су поетичка начела о којима се у песми говори и на плану форме преведена у конкретан поступак. Залажући се за незаинтересованост и равнодушност своје поезије (мотиви лепоте, гордости, равнодушности), Дучић се одриче стриктних и строгих прописа, те песму прилагођева колико сопственим поетичким назорима, толико духу и ритму језика којим пише. Као прилог оваквој тврдњи може се навести и закључак Ивана Негришорца: „Очигледно је, међутим, да Дучић сонетну форму схвата знатно лабавијом него што су, на темељу Петраркиног наслеђа, поетичари препоручивали. [...] Очигледно је он сматрао да је дуготрајно постојање овог облика довело до раздешенијих, слободнијих његових модуса који су савим легитимно укључени у песничку праксу. [...] Песма Поезија, отуда, није тек један рђаво начињен сонет; то је сонет који управо хоће да буде рђаво начињен јер тражи путеве тихог оспоравања и реинтеграције традиционалног облика” (Негришорац 2009: 25-27).

Стваралачки принципи евоцирани у претходним строфама (начело уздржаности, начело једноставности, начело лепоте по себи, начело стваралачке меланхолије) у завршним стиховима наткриљени су и уоквирени оним примарним - начелом поетског устројавања, односно прикладном формом песничког дела. Али и форма, попут девојчета што снева у природности своје ненаметљиве лепоте, треба само да евоцира оно неизрециво, сугестивно и алузивно. Да не казује, него да назначава. Да не буде саздана од речи (материје), него од алхемије језика, тј. од речитости духа свога творца.

\section{4. ЗАКЉУЧНЕ НАПОМЕНЕ}

Јован Дучић о српском језику није писао посебне есеје, али је у већини својих есеја и књижевно-критичких текстова разматрао језичка питања. Теоријска мисао о речима, синтакси, стилу, народном језику, поетском језику и песничком говору, у његовој критичкој поетици представљала је једну од доминантнијих тема. Ми смо у овом раду показали да значај Дучићевих критичких текстова није само у оригиналности књижевно-теоријских идеја или у домету ауторових заступања одређених стваралачких и естетичких принципа. Напротив, његова теоријска мисао о језику стоји у директном сагласју са поетском обрадом и применом теоријских експликација у непосредном стваралачком поступку. Такве чврсте везе између Дучићеве критичке поетике и поетског обликотворења теоријске мисли о стилу и језику сасвим су очигледне у његовој Поезији. Управо у овој песми сублимирани су закључци о језичким питањима који су иначе разасути у бројним есејима и књижевно-критичким записима. Иако је реч о програмској песми, показали смо да она не застаје на нивоу поетолошких објава или поетичког прогласа. Тумачење Поезије указало 
је да Дучићеви теоријски и поетолошки ставови оживљавају у сопственој примени, тј. да су ауторови поетички принципи синхроно превођени у конкретне стваралачке поступке. С тим у вези и његово потцртавање разлике између народног (општег) и поетског језика у структурирању ове песме остварило је своју непосредну поетску примену. Зато сматрамо да стварни значај програмске песме Поезија није примарно заснован ни у поетолошким рефлексијама ни у садржинском плану песме, већ у оригиналности и дометима поетског језика њеног творца.

\section{ЛИТЕРАТУРА}

Дучић 1969: Јован Дучић, Сабрана дјела, приредили Меша Селимовић и Живорад Стојковић, Сарајево: Свјетлост; Београд: Просвета.

Дучић 1969: Јован Дучић, „Моји сапутници: књижевна обличја. Прилози: Критике - Чланци - Белешке”, приредио Живорад Стојковић, у: Сабрана дјела књ. IV, Сарајево: Свјетлост; Београд: Просвета.

Дучић 1969а: Јован Дучић, „Јутра са Леутара: Речи о човеку. Стаза поред пута: Есеји. Прилози: Књижевно време -Уметност - Публицистика", приредио Живорад Стојковић, у Сабрана дјела књ. VI, Сарајево: Свјетлост; Београд: Просвета.

Дучић 1989: Јован Дучић, „Песме”, приредили Меша Селимовић и Живорад Стојковић, у: Сабрана дела, књ. І, БИГЗ, Сарајево: Свјетлост; Београд: Просвета.

Дучић 2000: Јован Дучић, „Благо цара Радована: књига о судбини; Јутра са Леутара: мисли о човеку", приредио Рајко Петров Ного, Београд: Рад; Подгорица: Октоих; Требиње: Дучићеве вечери поезије.

Дучић 2001: Јован Дучић, „Моји сапутници: књижевна обличја”, приредио Новица Петковић, у: Дела Јована Дучића књ. IV, Београд: Рад; Подгорица: Октоих, Требиње: Дучићеве вечери поезије.

Дучић 2001': Јован Дучић, „Стаза поред пута: есеји и чланци”, приредио Новица Петковић, у: Дела Јована Дучића књ. V, Београд: Рад; Подгорица: Октоих, Требиње: Дучићеве вечери поезије.

Данојлић 1979: Милован Данојлић, „Записи о Дучићу”, предговор избору Дучићеве поезије Сто песама, Београд: Слово љубве.

Матош 1952: Антун Густав Матош, Есеји и фељтони о српским писиима, Београд: Просвета. 
Милошевић 1993: Милош Милошевић, Рани Дучић, Нови Сад: Светови; Подгорица: Октоих.

Негришорац 2009: Иван Негришорац, „Поезија као унутрашња светлост: поетичке песме Јована Дучића („Поезија”, „Песма”, „Песма”)”, у: Поезија и поетика Јована Дучића: зборник радова, уредник Јован Делић, Београд: Институт за књижевност и уметност : Учитељски факултет; Требиње: Дучићеве вечери поезије.

Павловић 1981: Миодраг Павловић, Есеји о српским песнищима, Београд: Вук Караџић.

Петковић 2001: Новица Петковић, „Песник ,страшне међе””, у: Книжевност и језик, 1-2, 1-7, Београд: Друштво за српски језик и књижевност.

Петровић 2009: Svetozar Petrović, Nauka o književnosti, Beograd: Službeni glasnik.

Поповић 2011: Богдан Поповић, Антологија новије српске лирике, Београд: Српска књижевна задруга.

\section{ПОЭТИЧЕСКИЙ ЯЗЫК В ПРОГРАММНОМ СТИХОТВОРЕНИИ ПОЭЗИЯ ЙОВАНА ДУЧИЧА}

\section{Резюме}

Программное стихотворение Поэзия в данной работе толкуется с разных сторон. Внешний подход показал прочные связи теоретической мысли Дучича (критическая поэтика) и программных сообщений о стихотворении, поэте, творчестве, стиле и поэтическом языке, которые автором в Поэзии лирически оформлены. С другой стороны, результаты внутреннего подхода толкования подтвердили наглядную обусловленность и связи по соблюдению поэтических принципов и их применению в структурировании стихотворения. Итак, в статье мы показали, что поэтический язык является не только теоретическим или поэтологическим замыслом, а представляет собой оригинальный творческий концепт и своеобразный стиль и языковые особенности автора - т.е. олицетворяет поэтический принцип перенесенный в конкретный творческий подход. 